Вопросы языкознания 2013-2023

ISSN 2079-8784

URL - $\underline{\text { http: }} \underline{\text { /ras.jes.su }}$

Все права защищены

Номер 5 Том . 2018

\title{
Рецензия на: S. Hancil, A. Haselow, M. Post (eds.). Final particles. Berlin: De Gruyter Mouton, 2015
}

\section{Панов Владимир Александрович}

Институт языкознания РАН

Москва, Россия

Аннотация

Ключевые слова:

Дата публикации: 08.10.2018

Ссылка для цитирования:

Панов В. А. Рецензия на: S. Hancil, А. Haselow, M. Post (eds.). Final particles. Berlin: De Gruyter Mouton, 2015 // Вопросы языкознания - 2018. - Номер 5 C. 124-130 [Электронный pecypc]. URL: http://ras.jes.su/vopjaz/s207987840000638-0-1 (дата обращения: 26.04.2023). DOI: 10.31857/S0373658X0001401-0

Подписки не найдены

\section{Библиография:}

1. Панов 2016 - Панов В. А. Бурятские заключительные частицы в ареальнотипологической перспективе // Урало-алтайские исследования. 2016. №4 (23). С. $121-128$.

2. Прасол 1999 - Прасол А.Ф. Заключительные модально-экспрессивные частицы в японской речи. Владивосток: издательство Дальневосточного Федерального 
3. Blakemore 1987 - Blakemore D. Semantic constraints on relevance. Oxford: Blackwell, 1987.

4. Chan 2013 - Chan B. H.-Sh. Sentence-final particles, complementizers, antisymmetry, and the finaloverfinal constraint. Theoretical approaches to disharmonic word order. Biberauer Th., Sheehan M. (eds.). Oxford: Oxford Univ. Press, 2013. Pp. $445-468$.

5. Cinque 1999 - Cinque G. Adverbs and functional heads: A cross-linguistic perspective. Oxford: Oxford Univ. Press, 1999.

6. Cooke 1989 - Cooke J. R. Thai sentence particles: Forms, meanings, and formalsemantic variations. Papers in Southeast Asian Linguistics. 1989. Vol. 12. No. 12. Thai Sentence Particles and Other Topics. Pp. 1-90.

7. Foolen 1994 - Foolen A. [Review of:] Andvik E. Pragmatic analysis of the Norwegian modal particles. Lingua. Vol. 93. No. 4. Pp. 307-312.

8. Foolen 1996 - Foolen A. Pragmatic Particles. Handbook of pragmatics. Verschoeren J., Ola-Östmann J., Blommaert J., Bulcaen C. (eds.). Amsterdam: John Benjamins, 1996.

9. Haselow 2012 - Haselow A. Subjectivity, intersubjectivity and the negotiation of common ground in spoken discourse: Final particles in English. Language \& Communication. Vol. 32. No. 3. Pp. 182-204.

10. Heine et al. 2013 - Heine B., Kaltenböck G., Kuteva T., Long H. An outline of discourse grammar. Functional approaches to language. Boschoff Sh., Jany C. (eds.). Berlin: De Gruyter Mouton, 2013. Pp. 175-233.

11. Hopper 1991 - Hopper P. J. On some principle of grammaticalization. Approaches to grammaticalization. Vol. 1. Traugott E., Heine B. (eds.). Amsterdam: John Benjamins, 1991. Pp. 17-35.

12. Kayne 1994 - Kayne R. The antisymmetry of syntax. Cambridge: MIT Press, 1994.

13. Le 2015 - Le G. H. Vietnamese sentence final particles. PhD diss. Los-Angeles: Univ. of Southern California, 2015.

14. Linell 2005 - Linell P. The written language bias in linguistics: Its nature, origins, and transformations. London: Routledge, 2005.

15. Luke 1990 - Luke K. K. Utterance particles in Cantonese conversation. Amsterdam: John Benjamins, 1990.

16. Mulder, Thompson 2008 - Mulder J., Thompson S. The grammaticalization of but as a final particle in English conversation. Crosslinguistic studies of clause combining: 
The multifunctionality of conjunctions. Laury R. (ed.). Amsterdam: John Benjamins, 2008. Pp. 179-204.

17. Ogden 2004 - Ogden R. Non-modal voice quality and turn-taking in Finnish. Sound patterns in interaction. Couper-Kuhlen E., Ford C. E. (eds.). Amsterdam: John Benjamins, 2004. Pp. 29-62.

18. Shapiro 2012 - Shapiro R. Chinese Pidgin Russian. Pidgins and creoles in Asia. Ansaldo U. (ed.). Amsterdam: John Benjamins, 2012. Pp. 1-58.

19. Sperber, Wilson 1986 / 1995 - Sperber D., Wilson D. Relevance: Communication and cognition. Oxford: Blackwell, 1986; 2nd ed. with a postface 1995.

20. Thompson, Suzuki 2012 - Thompson S., Suzuki R. The grammaticalization of final particles. The Oxford handbook of grammaticalization. Narrog H., Heine B. (eds.). London: Oxford Univ. Press, 2012. Pp. 668-680.

21. Traugott 2010 - Traugott E. (Inter)subjectivity and (inter)subjectification: A reassessment. Subjectification, intersubjectification and grammaticalization. Davidse K., Vandelotte L., Cuyckens H. (eds.). Berlin: De Gruyter Mouton, 2010. Pp. 29-71. 


\section{Review of the book: S. Hancil, A. Haselow, M. Post (eds.). Final particles. Berlin: De Gruyter Mouton, 2015}

\section{Vladimir Panov}

Institute of Linguistics, Russian Academy of Sciences

Moscow, Russia

Abstract

Keywords:

Publication date: 08.10 .2018

Citation link:

Panov V. Review of the book: S. Hancil, A. Haselow, M. Post (eds.). Final particles. Berlin: De Gruyter Mouton, 2015 // Voprosy Jazykoznanija - 2018. - Issue 5 C. 124-130 [Electronic resource]. URL: http://ras.jes.su/vopjaz/s207987840000638-0-1 (circulation date: 26.04.2023). DOI: 10.31857/S0373658X0001401-0

Код пользователя: 0; Дата выгрузки: 26.04.2023; URL - http://ras.jes.su/vopjaz/s207987840000638-0-1 Bce права защищены. 